\author{
Nina P. Efimova ${ }^{1}$ \\ Aleksandr A. Vasilev \\ Anatoly B. Yaroshchuk
}

Article info: Received 20.09.2020 Accepted 12.02.2021

$\mathrm{UDC}-005.6$ DOI - 10.24874/IJQR15.04-10

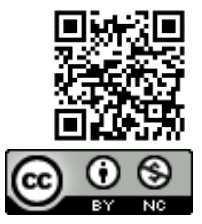

\section{QUALITY MANAGEMENT OF ENVIRONMENTAL PROTECTION IN THE ACTIVITY OF SUPREME AUDIT INSTITUTIONS IN VARIOUS STATES AND THE PROSPECTS FOR IMPROVING THE QUALITY BASED ON INDUSTRIAL AND MANUFACTURING ENGINEERING}

\begin{abstract}
The paper is aimed at identifying the prospects for improving the quality based on industrial and manufacturing engineering, as well as developing recommendations to improve the quality management of environmental protection in the activity of supreme audit institutions in various states based on industrial and manufacturing engineering. The originality of the research is attributable to the focus on the quality and prospects for improving it in environmental protection in the activity of supreme audit institutions in various states. The paper not only justifies the need for improving the quality, but also identifies accurate quantitative benchmarks (reference values of quality indicators and their factors), gives applied recommendations to improve the quality of environmental protection in the activity of supreme audit institutions in various states based on industrial and manufacturing engineering. The authors' recommendations are oriented toward a realistic (feasible) scenario and involve ensuring the beneficial effect of industrial and manufacturing engineering by increasing the degree of beneficial effect of industrial and manufacturing engineering factor to 100 points $(+31.19 \%)$. This will cause an increase in the strength of auditing and accounting standards to $15.95 \%$ and an increase in the degree of renewable energy regulation to $11.19 \%$. As a result, this allows decreasing the level of environmental pollution by $42.08 \%$ and increasing the Climate Index to 5.39\%.
\end{abstract}

Keywords: Quality; Quality Management; Financial Control; State Audit; Supreme Audit Institutions; Environmental Protection; Industrial and Manufacturing Engineering.

\section{Introduction}

The problem of the state of the environment is becoming very acute both for the entire world and for individual countries. The interest in the study of the state of the environment is under the closest scrutiny of the United Nations (UN). It is not by chance that a sustainable development concept was developed by the UN as early as in 1980 to provide for the agreed solution of economic, environmental and social problems by the

1 Corresponding author: Nina P . Efimova

Email: active email adress 
states.

Supreme audit institutions, established in various states worldwide, provide support to governments in improvement of the effectiveness, strengthening of transparency and public confidence, provision of accountability, support of objectivity, fight against corruption, assistance in efficient and effective acquisition and utilization of public resources (Klimanov et al., 2019).

The growing trends towards expansion of the fields of activity of supreme audit institutions in various states have currently been observed. In spite of different auditing approaches, supreme audit institutions of foreign countries are actively engaged in environmental audits and environmental protection. The methodological basis for such work is represented by the standards of the International Organization of Supreme Audit Institutions (INTOSAI) for the implementation of environmental audit.

The analysis of literary sources and the experience of the International Organization of Supreme Audit Institutions (INTOSAI) have been used to identify the role of the Audit Chamber of the English Federation during the environmental audit in the context of similar activity of supreme audit institutions (SAI) affiliated with the INTOSAI.

The core of this research consists of the study and analysis of the content of supreme audit institutions in various states, prepared based on the results of the audit of air pollution, water pollution and waste management in member countries. The abovementioned reports were published in IDI-Environmental Auditing Workshop (2004), and in such standards as ISSAI 5110 Guidance on Conducting Performance Audit with an Environmental Perspective (2016), ISSAI 5120 Environmental Auditing in The Context of Financial and Compliance Audits (2016), ISSAI 5140 How SAIs May Cooperate on The Audit of International Environmental Accords (2016).
This research took into consideration the opinions of various scientists and specialists in solving environmental problems through interaction of external and internal audit institutions in various states to prevent risks during natural resources utilization (Chkhutiashvili L., Dulkis A., Mitrik K.). The analysis of results of environmental audits in particular countries, including Russia, caused the need for a more in-depth research on this topic, since supreme audit institutions in various states use different methods in the pursuance of such a research.

The center of attention in this reseacrh is the problem which consists in the ambiguity about the prospects for managing the quality of environmental protection in the activity of supreme audit institutions in different states and quality improvement sources. The existence of this problem causes a focus on quantitative indicators (e.g. amount of financing) in the activity of supreme audit institutions in various states in environmental protection. However, experience has proven that quantitative indicators show little correlation with results, which translates into low management efficiency and uncertainty of national audit data in various states in environmental protection. Therefore, a reorientation towards quality as a reliable indicator of audit (control) is needed.

The working hypothesis of the research is that the factors of industrial and manufacturing engineering allow improving the quality in environmental protection in the activity of supreme audit institutions in various states. The mission of this paper is to identify the prospects for improving the quality based on industrial and manufacturing engineering, as well as to develop recommendations to improve the quality management of environmental protection in the activity of supreme audit institutions in various states based on industrial and manufacturing engineering. 
The originality of the research is attributable to the focus on the quality and prospects for improving it in environmental protection in the activity of supreme audit institutions in various states. The advantage of the research is its applied focus. The paper not only justifies the need for improving the quality, but also identifies accurate quantitative benchmarks (reference values of quality indicators and their factors), gives applied recommendations to improve the quality of environmental protection in the activity of supreme audit institutions in various states based on industrial and manufacturing engineering. The scientific novelty of the research consists in the clarification of methodological approaches during environmental audits through interaction with the parties concerned in conjunction with highly-qualified personnel in the field of environmental protection.

The structure of the paper consists of Introduction, Literature Review, Methodology, and Results, in particular: 1) identifying the trends in the activity of supreme audit institutions in various states in the field of environmental protection and their interpretation from a quality perspective; 2) a case study on environmental protection in the activity of national supreme audit institutions in Russia and a critical look at it from a quality perspective; 3 ) developing recommendations to manage the quality of environmental protection in the activity of supreme audit institutions in various states based on industrial and manufacturing engineering, as well as Discussion and Conclusion.

\section{Literature Review}

Environmental protection issues in the context implementation of sustainable development goals in respect of the aspect of combating climate change are covered in the writings of such authors as Fulton (2020), Meng et al. (2020), Rahman et al. (2020), and Ralston et al. (2020). The activity of supreme audit institutions in various states in environmental protection was discussed in works of such as researchers as Di Giacomo et al. (2017), Henri et al. (2017), Kumar et al. (2017), Ma (2017), Ong et al. (2019), Rötzel et al. (2019), Walimuni et al. (2017). Quality management issues in environmental protection were discussed in publications of Makarova et al. (2018), Muthukannan and Ganesh (2019).

The literature review has revealed high degree of elaboration of individual components of the problem studied in the paper. Thus, certain quality management issues in environmental protection are discussed in existing publications, yet without reference to the activity of supreme audit institutions in various states, the ambiguity of scientific interpretation of quality in which constitutes a gap in currently available knowledge. Another gap consists in the obscure prospects for improving the quality, and, in particular, in the understudied contribution of industrial and manufacturing engineering. In order to fill the identified gaps, this paper presents a comprehensive study of the issues of quality management of environmental protection in the activity of supreme audit institutions in various states and the prospects for improving the quality based on industrial and manufacturing engineering.

\section{Methodology}

The logic of verification of the current hypothesis of the research involves a comprehensive economic analysis. In the empirical part of the research (4.3), the correlation analysis method is used to determine the nature and the ratio of correlation of quality indicators in environmental protection in the activity of supreme audit institutions in various states (quality of land administration, strength of auditing and accounting standards, government's responsiveness to change, government long-term vision, renewable 
energy regulation, as well as environmentrelated treaties in force, calculated by the World Economic Forum, 2020) with the environmental impact (Environmental Pollution Index and Climate Index, calculated by Numbeo, 2020).

Those quality indicators that have a strong (a correlation over $10 \%$ in absolute value) and positive impact on both results are selected; in other words, they demonstrate a negative correlation with the Environmental Pollution Index and a positive correlation with the Climate Index, calculated by the IMD (2020). Exact dependences are determined for selected indicators using the regression analysis method with the construction of regression curves.

In the following, regression dependences are determined for selected quality indicators in environmental protection in the activity of supreme audit institutions in various states from the factor of industrial and manufacturing engineering, which is represented by the Digital Competitiveness Index. A simplex method is used for the scenario analysis, and reference values of indicators under different scenarios are determined.

The research is conducted through the example of the TOP-5 developed countries (Germany, France, Finland, Denmark and Sweden) and the TOP-5 developing countries (Russia, Brazil, China, Thailand, Chile) with the highest value of the Sustainable Development Index in 2020 (Figure 1).

\section{Developed countries}

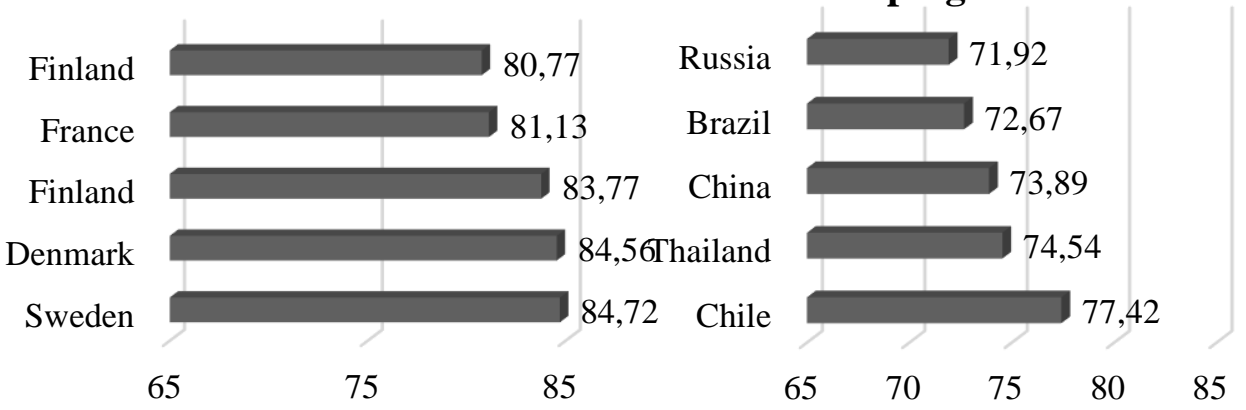

Figure 1. Characteristics of a sample of countries from the perspective of the Sustainable

Development Index in 2020, points 1-100

Source: constructed by the authors based on materials of the UNPD (2020).

Thanks to inclusion of research results for both developed and developing countries in the sample, authors' conclusions and recommendations are of interest and may turn out to be beneficial to any countries of the world. The survey sample is defined in Table 1.

The case-study part of the paper $(4.1,4.2)$ is based on the study and analysis of reports on control over more than 10-year period in the field of environmental management and environmental protection of supreme audit institutions. Comparative analysis methods, as well as compliance and matching methods have been used in the research. The summary of reports and audit results was published by the International Organization of Supreme Audit Institutions (INTOSAI), Asian Organization of Supreme Audit Institutions (ASOSAI), Organization for Economic Cooperation and Development (OECD), Audit Chamber of the Russian Federation, and internal control institutions of economic entities using natural resources in their activity, on relevant websites and in relevant scholarly journals. 
Table 1. Statistical basis of the research

\begin{tabular}{|c|c|c|c|c|c|c|c|c|c|}
\hline - & $\begin{array}{r}\text { Quality } \\
\text { su }\end{array}$ & $\begin{array}{l}\text { in enviro } \\
\text { preme auc }\end{array}$ & $\begin{array}{r}\text { nmental } \\
\text { it institut } \\
\text { points }\end{array}$ & $\begin{array}{l}\text { rotectio } \\
\text { ons in } \\
1-100\end{array}$ & $\begin{array}{l}\text { in the a } \\
\text { rious st }\end{array}$ & $\begin{array}{l}\text { vity of } \\
\text { s, }\end{array}$ & $\begin{array}{l}\text { Environ } \\
\quad \text { imp }\end{array}$ & $\begin{array}{l}\text { nental } \\
\text { ct }\end{array}$ & $\begin{array}{c}\text { Industrial and } \\
\text { manufacturing } \\
\text { engineering } \\
\text { factor }\end{array}$ \\
\hline Country & 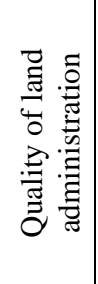 & 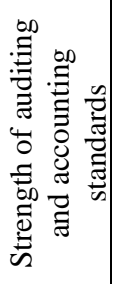 & 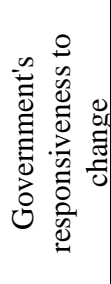 & 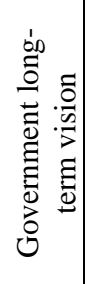 & 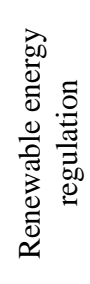 & 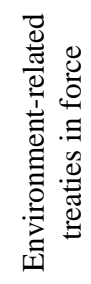 & 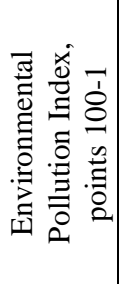 & 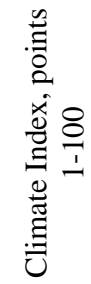 & 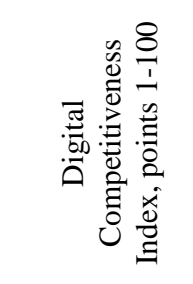 \\
\hline & $\mathrm{x}_{1}$ & $\mathrm{x}_{2}$ & $\mathrm{x}_{3}$ & $\mathrm{X}_{4}$ & $\mathrm{x}_{5}$ & $\overline{\mathrm{x}_{6}}$ & $\mathrm{y}_{1}$ & $\mathrm{y}_{2}$ & i\&me \\
\hline Sweden & 91.7 & 82.8 & 56.1 & 55.6 & 80.4 & 100.0 & 19.05 & 73.97 & 95.146 \\
\hline Denmark & 81.7 & 79.0 & 60.7 & 62.8 & 73.9 & 100.0 & 21.52 & 89.78 & 96.013 \\
\hline Finland & 88.3 & 92.2 & 69.9 & 67.9 & 70.6 & 100.0 & 11.79 & 59.21 & 91.130 \\
\hline France & 80.0 & 73.9 & 56.0 & 58.8 & 86.3 & 97.0 & 43.64 & 83.78 & 76.983 \\
\hline Germany & 73.3 & 73.0 & 60.0 & 59.0 & 96.6 & 10.0 & 29.28 & 83.15 & 81.062 \\
\hline Chile & 46.7 & 77.4 & 50.0 & 56.4 & 72.8 & 83.0 & 79.74 & 90.21 & 61.518 \\
\hline Thailand & 63.3 & 65.6 & 47.9 & 49.1 & 47.0 & 72.0 & 75.26 & 69.45 & 64.265 \\
\hline China & 79.0 & 59.1 & 49.8 & 57.9 & 66.4 & 83.0 & 79.88 & 78.17 & 84.105 \\
\hline Brazil & 46.0 & 61.1 & 29.2 & 23.9 & 70.9 & 86.0 & 54.67 & 94.10 & 52.095 \\
\hline Russia & 86.7 & 54.6 & 47.4 & 51.0 & 59.9 & 66.0 & 62.58 & 39.51 & 59.950 \\
\hline
\end{tabular}

Source: compiled by the authors based on materials of the IMD (2020), Numbeo (2020), and the World Economic Forum (2020)

\section{Results}

4.1 Trends in the activity of supreme audit institutions in various states in the field of environmental protection and their interpretation from a quality perspective

Deterioration of the state of the environment throughout the world is indicative of the incorrect utilization of natural resources, air pollution, water pollution, near-shore pollution, increase in the level of dumping of industrial and household waste, which endangers biodiversity and environmental well-being. Influencing measures must be taken by audit institutions at various levels to resolve such a situation.

It is not by chance that the International Organization of Supreme Audit Institutions (INTOSAI) approved environmental audit standards. For example, it approved the standard ISSAI 5120 "Environmental
Auditing in the Context of Financial and Compliance Audits". According to this standard, environmental audit shall be understood to mean performance audit, compliance audit or fiscal audit, which treats the approach of relevant authorities to a particular environmental problem, or environmental programs or policies and their efficiency when solving environmental problems.

Article 1 of the Federal Law of January 10, 2002 "On Environmental Protection" of the Russian Federation defines environmental audit as an independent, comprehensive, documented assessment of compliance with the requirements by a legal entity or a selfemployed individual, including guidelines and regulations, federal rules and regulations in the field of environmental protection, requirements of international standards, and development of recommendations for the improvement of such activity. In other 
words, environmental audit can be treated within the given context as the control procedure in the field of assessment of the state of the environment.

In individual states affiliated with the INTOSAI, environmental audit is conducted on a regular basis and its results are broadly communicated to society and reported to the public authorities, thus allowing to prevent environmental risks to some extent.

Selected results of environmental audits conducted by supreme audit institutions in INTOSAI member countries are shown in Table 2.

Table 2. Selected results of environmental audits conducted by supreme audit institutions in INTOSAI member countries

\begin{tabular}{|c|c|c|}
\hline SAI country & Name of audit, type of audit & Year \\
\hline \multicolumn{3}{|c|}{ Environmental audit of air pollution } \\
\hline Australia & Managing major programs, performance audit & $\begin{array}{l}2003 \\
2004\end{array}$ \\
\hline India & $\begin{array}{l}\text { Pollution control exercised by the Department of Transportation, Mizoram, } \\
\text { compliance audit }\end{array}$ & 2006 \\
\hline India & $\begin{array}{l}\text { Environmental management system for public sector activities in Uttar } \\
\text { Pradesh, performance audit }\end{array}$ & 2005 \\
\hline Japan & Project to control the carbon dioxide level, performance audit & 2005 \\
\hline Kuwait & $\begin{array}{l}\text { Environmental audit in the region of Ali Al Salem (Um Al-Hayman), } \\
\text { performance audit }\end{array}$ & 2006 \\
\hline Saudi Arabia & $\begin{array}{l}\text { Performance audit of the preservation of the natural environment by the } \\
\text { energy company }\end{array}$ & 2008 \\
\hline Saudi Arabia & Performance audit at the cement works & 2004 \\
\hline \multicolumn{3}{|c|}{ Environmental audit of water pollution } \\
\hline Denmark & Audit of activities in Denmark in the Arctic region & 2014 \\
\hline Brazil & $\begin{array}{l}\text { The Federal Court of Accounts (TCU) and nine Audit Chambers of the } \\
\text { Brazilian Amazon conducted a joint audit of the state of specially protected } \\
\text { natural sites in the Amazon biome }\end{array}$ & $\begin{array}{l}2011- \\
2012\end{array}$ \\
\hline Estonia & $\begin{array}{l}\text { Audit "Provision and proper use of grants and support provided to } \\
\text { foundations established by the State", in the framework of which, among } \\
\text { other activities, the audit of Environmental Investment Center was held, } \\
\text { fiscal audit }\end{array}$ & 2014 \\
\hline Cyprus & $\begin{array}{l}\text { Marine pollution due to shipping traffic - Joint Report based on national } \\
\text { audits - } 2003\end{array}$ & 2006 \\
\hline Korea & Prevention of marine pollution, performance audit & 2006 \\
\hline Indonesia & $\begin{array}{l}\text { Performance audit of activities held by government authorities in the } \\
\text { Brantas River basin }\end{array}$ & 2014 \\
\hline \multicolumn{3}{|c|}{ Environmental audit of waste management } \\
\hline Malaysia & $\begin{array}{l}\text { Nilai Municipal Council - Privatization of domestic waste removal and } \\
\text { disposal services }\end{array}$ & 2006 \\
\hline Turkey & Waste management in Turkey - national provisions and appraisal of results & 2007 \\
\hline
\end{tabular}

Source: compiled by the authors based on materials of the INTOSAI (2020).

The following results were obtained from abovementioned audits. Thus, in the report of the Supreme Audit Institution of India Comptroller and Auditor General - CAG (for 2006), it is claimed that the government is unable to install the emissions testing equipment, which not only resulted in the use of 49,826 machines without "Pollution Control Certificate" during 2004-2005 and 2005-2006, but also in the loss in income in the amount of $2.99 \times 10$ million rupee. At the same time, the presence of the associated 
risk of environmental pollution has been observed.

Comptroller and Auditor General - CAG of India held the performance audit of the environmental management system for public sector activities in Uttar Pradesh, India, in 2005; based on this audit, it was established that there was no environmental management system under any public sector activities. Public sector activities did not comply with many provisions of the Law on management of air and water protection, solid waste recycling, and treatment of hazardous wastes.

In the report of the Supreme Audit Institution of Japan - Board of Audit, it is concluded that the grants for the implementation of the project to control the level of carbon dioxide emissions have not achieved their goal. Since the capacity of a small wind-driven heater was lower than the amount of electricity consumed, there was no reduction in carbon dioxide emission (1 case; 185 million Yen).

In the report of the Supreme Audit Institution of Indonesia, it is noted that an increase in expenses for water purification depends on the amount of water pollutants. This leads to a rise in tariffs, affecting the poor the most.

During the fiscal auditing in the Ministry of Environment by the Supreme Audit Institution of Estonia, no misuse of public funds was found, and a fairly efficient management system was revealed. However, the auditors noted that the rules for the allocation of funds were not transparent, and the rights of the founder and the actual supervision over the fund were exercised by different ministries (the Ministry of Environment and the Ministry of Finance) for no apparent cause.

Within the framework of the research, attention was drawn to the fact that during the audit in most States, one of the facts of reliability of acquired audit evidence is believed to be the acquisition of information about the efficiency of internal audit of an enterprise, which is indicative of the increased focus on quality.

Risk assessment, which is also related to quality, is one of the main elements of the internal audit system. Global practice has adopted an approach, in accordance with which organizations should keep a register of risks, where all risks are included, their significance is assessed, and agreed measures to eliminate them are recorded (Efimova and Terekhina, 2016). Taking into account international experience, one of the trends of functioning of the Supreme Audit Institution in reception of audit evidence is the mandatory analysis of results of internal audit institutions of organizations and the definition of responsibility of this institution for the state of the environment, which contributed to reliability and quality.

\subsection{A case study on environmental protection in the activity of national supreme audit institutions in Russia: a critical look from a quality perspective}

In Russia, inspections of the application of funds in the field of environmental protection fall within the scope of the Audit Chamber of the Russian Federation from the moment it was established, yet from the perspective of not only application of funds, but also utilization of natural resources and the state of the environment they have only become important in recent years, especially since the National Project "Environment" was approved.

The primary focus during environmental audits in Russia is on the application of funds, while the fiscal audit is held during the monitoring with a view to identifying environmental problems. A lot of budgetary provisions are made for these activities. The changes in the pattern of budget expenditures for the implementation of government programs in the field of environmental management and environmental protection in 2017-2021 are shown in Figure 2. 


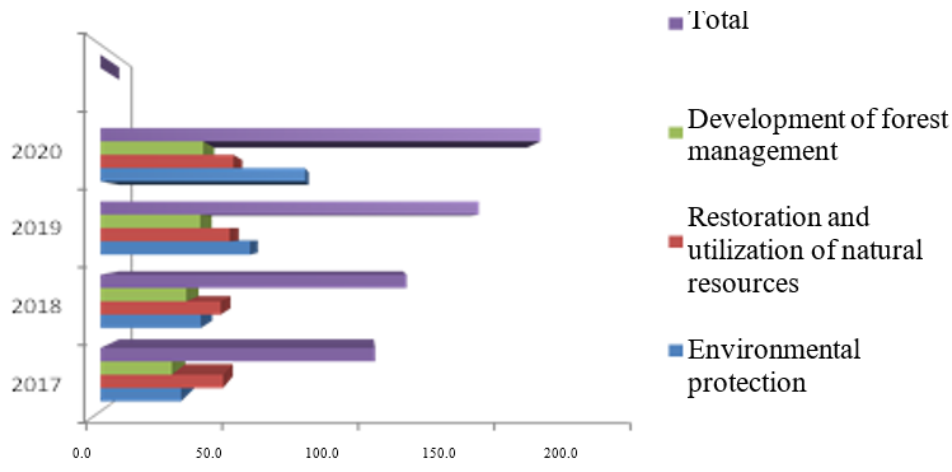

Figure 2. Changes in the pattern of budget expenditures for the implementation of government programs in the field of environmental management and environmental protection in 2017-2021, billion rubles

Source: constructed by the authors based on materials of the Ministry of Finance of the Russian Federation (2020).

The changes in the total volume of national budget expenditures for the implementation of government programs in the field of environmental management and environmental protection are characterized by a stable growth in budget allocations by a mean of $12.5 \%$ a year, which requires systemwide activities of the Audit Chamber of the Russian Federation.

In addition, the most significant activities of the Audit Chamber of the Russian Federation have been carried out over the last three years on such socially sensitive topics as:

- functioning of the water resources management system and elimination of floods;

- $\quad$ protection from fires, protection and utilization of forest resources;

- ensuring safe municipal solid waste management and elimination of facilities that cause accumulated damage to the environment to the environment.

Attention to these topics is reflective of the desire to improve the quality of environmental audit in Russia.

The results of monitoring of the Federal Project "Integrated municipal solid waste management" that was conducted by the
Audit Chamber of the Russian Federation testified that a comprehensive waste management reform had never been initiated, in particular, due to the shortcomings of the legal and regulatory framework.

The Audit Chamber of the Russian Federation conducted the fiscal audit of the Federal Project "Fresh Air" (2020), which demonstrated the inadequacy of activities to improve air quality. Thus, in Krasnoyarsk the largest city in the region in terms of population size with an extremely high air pollution level - average annual concentrations of benz(a)pyrene and formaldehyde exceed the maximum permissible concentration (MPC) 7 times, which is clearly shown in Figure 3.

The relocation of pollutants from the city is hampered by land topography and climatic conditions.

The results of the fiscal audit have shown that thanks to activities that were implemented in the framework of the Federal Project "Fresh Air", there will be an almost double decrease in benz(a)pyrene concentration; however, the air pollution level will still be high due to emissions from small coal-fired boiler-houses and road transport. 
TREND TOWARDS THE CHANGE IN AIR QUALITY THROUGH THE EXAMPLE OF KRASNOYARSK
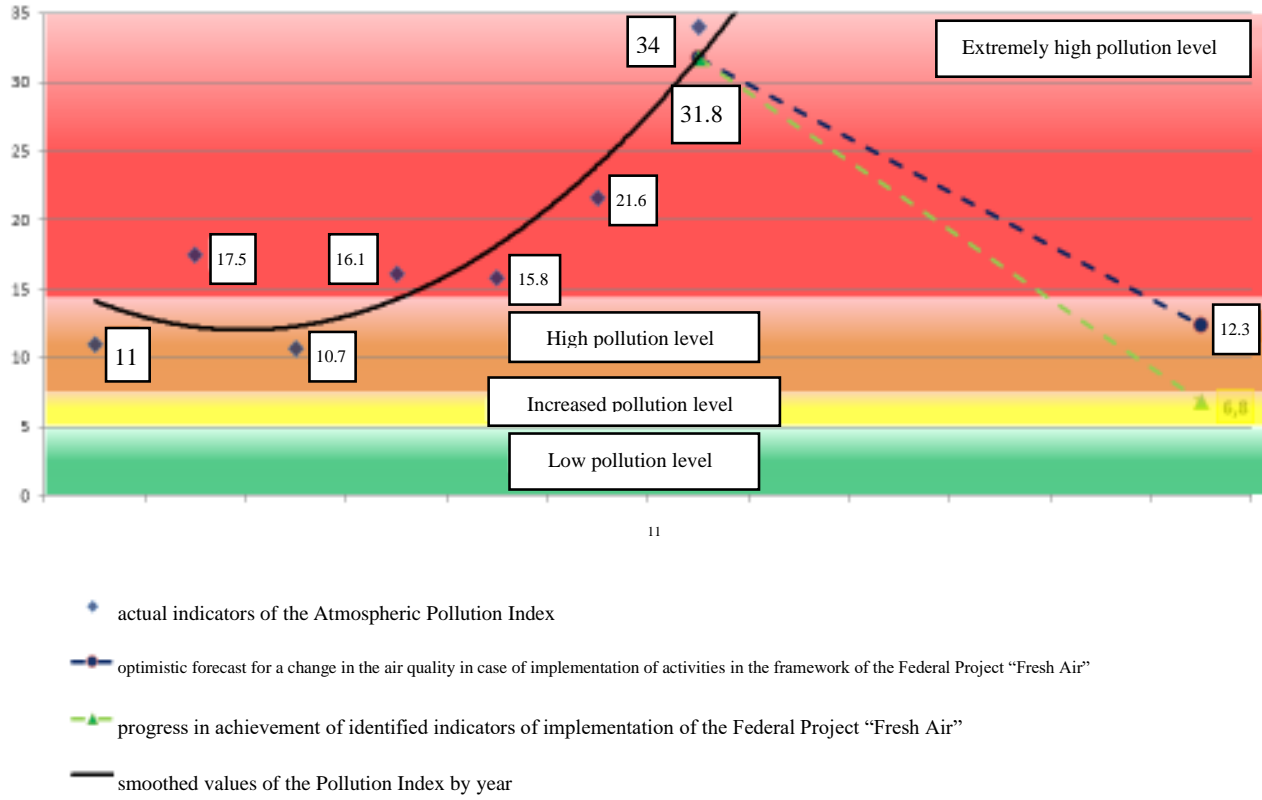

Figure 3. Fiscal audit of the Federal Project "Fresh Air" in Russia in 2020 through the example of Krasnoyarsk

Source: compiled by the authors based on materials of the Audit Chamber of the Russian Federation (2020).

The assimilation of experiences of countries affiliated with the International Organization of Supreme Audit Institutions (INTOSAI), in the field of environmental audit has revealed a great variety of approaches to its implementation.

As a result of this research, the scholars, with due account for experience of supreme audit institutions of foreign countries, consistently concluded that environmental audit is a set of mechanisms that are used during the fiscal audit, performance audit or compliance audit, and represents a dynamic system of environmental audits, which is adapting to ever-changing sociopolitical realia.
Training of specialists in economics of environmental management and environmental protection has a significant impact with such a type of audit, since it allows using a variety of tools for reception of audit evidence during environmental audits.

According to surveys held by the working group of the INTOSAI on environmental audit, one of the main obstacles to conducting such audits is, inter alia, the lack or absence of necessary experience, knowledge and skills in employees of supreme audit institutions, which has a detrimental effect on quality. Appropriate training could be a way to resolve this problem. 


\subsection{Recommendations to manage the quality of environmental protection in the activity of supreme audit institutions in various states based on industrial and manufacturing engineering}

In order to identify the contribution of quality management in the activity of supreme audit institutions in various states to environmental results, we shall turn to results of the correlation analysis of data from Table 1 (Figure 4).

Based on results of the correlation analysis shown in Figure 4, two quality manifestations in the activity of supreme audit institutions in various states have been selected, which demonstrate a pronounced (more than $10 \%$ in absolute value) and necessary correlation with both environmental results. They are as follows: strength of auditing and accounting standards, which has demonstrated a correlation of $-71.90 \%$ with the Environmental Pollution Index and a correlation of $16.27 \%$ with the Climate Index, as well as renewable energy regulation, which has demonstrated a correlation of $-54.92 \%$ with the Environmental Pollution Index and a correlation of $44,03 \%$ with the Climate Index.

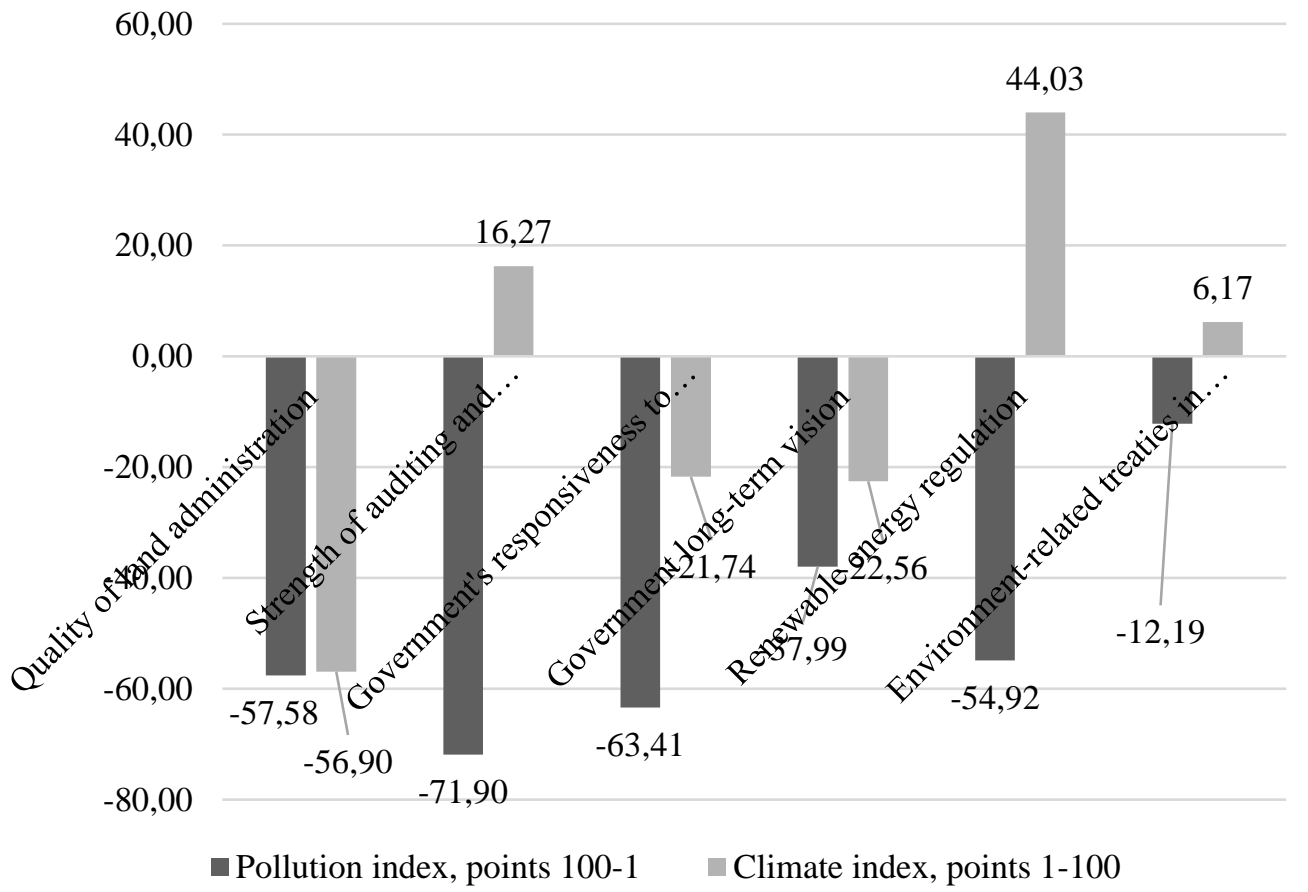

Figure 4. Correlation of quality manifestations in the activity of supreme audit institutions in various states with environmental results in $2020, \%$

Source: calculated and constructed by the authors

Regression statistics has been calculated for selected indicators:

- $\mathrm{y}_{1}=186,56-1,33 \mathrm{x}_{2}-0,59 \mathrm{x}_{5}$. According to the regression equation obtained, with a 1-point increase in the strength of auditing and accounting standards, there is a 1.33-point decrease in the level of environmental pollution. With a one- 
point increase in the degree of renewable energy regulation, there is a 0.59 -point decrease in the level of environmental pollution. The coefficient of correlation 0.7720 is a reflection of the fact that the level of environmental pollution of $77.20 \%$ is attributable to the impact of selected quality manifestations in the activity of supreme audit institutions in various states;

- $\mathrm{y}_{2}=38,62-0,03 \mathrm{x}_{2}+0,54 \mathrm{x}_{5}$. According to the regression equation obtained, with a 1-point increase in the strength of auditing and accounting standards, there is a 0.03 -point decrease in the Climate Index. (expectations were not satisfied based on results of the correlation analysis, which will make subsequent optimization more complex). With a onepoint increase in the degree of renewable energy regulation, there is a 0.54 -point increase in the Climate Index. The coefficient of correlation 0.4406 is a reflection of the fact that the Climate Index is by $44.06 \%$ attributable to the impact of selected quality manifestations in the activity of supreme audit institutions in various states.

For selected quality manifestations in the activity of supreme audit institutions in various states, we shall determine the degree of their dependence on the factor of industrial and manufacturing engineering (Figure 5).

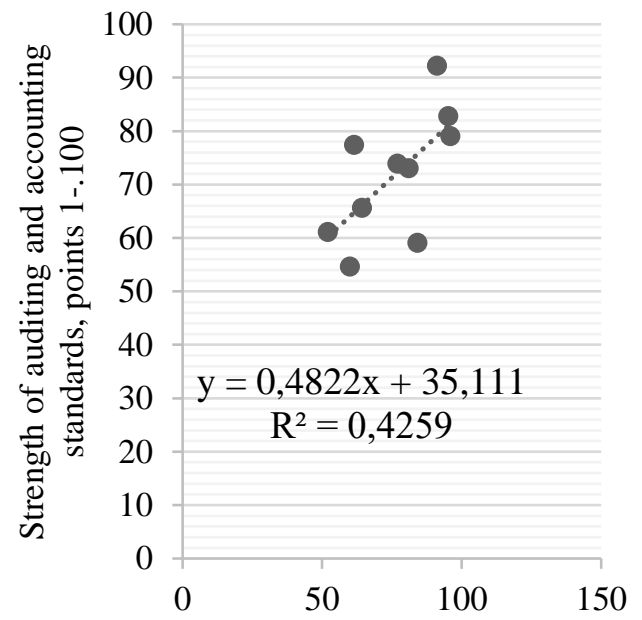

Digital Competitiveness Index, points $1-100$

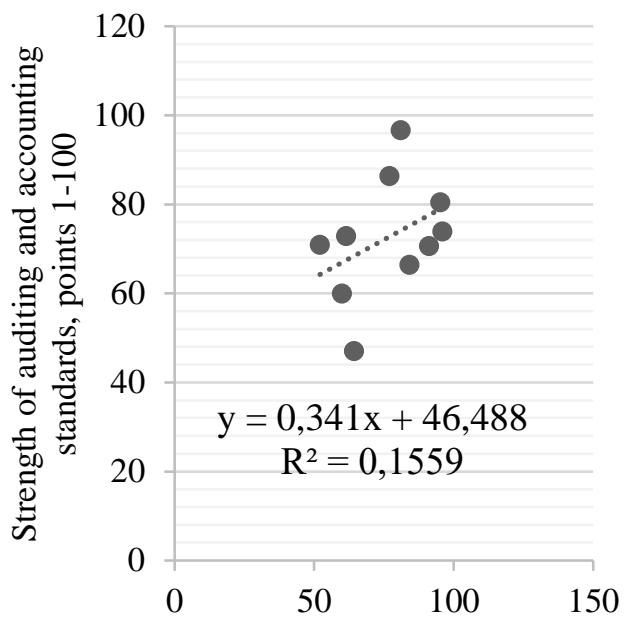

Digital Competitiveness Index, points $1-100$

Figure 5. Regression curves of dependence between environmental results and selected quality manifestations in the activity of supreme audit institutions in various states

Source: calculated and constructed by the authors.

As can be seen from Figure 5, with a onepoint increase in the Digital Competitiveness Index, there is a 0.4822 -point increase in the strength of auditing and accounting standards and a 0.341-point increase in the degree of renewable energy regulation. This is indicative of a positive impact of the factor of industrial and manufacturing engineering on selected quality manifestations in the activity of supreme audit institutions in various states. The results of the regression analysis make it possible to carry out the scenario analysis, the results of which are shown in Figures 6,7 . 


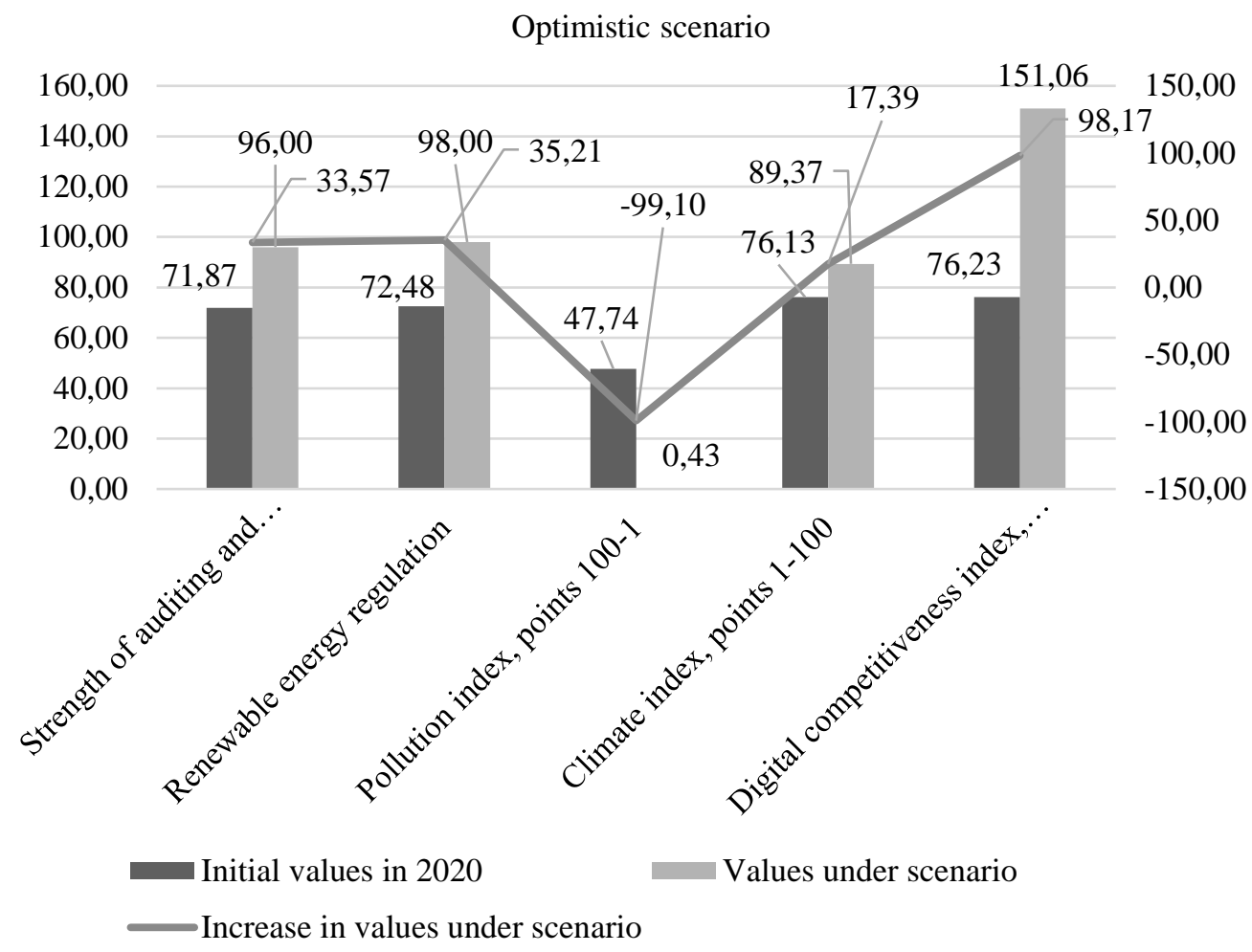

Figure 6. Maximization of environmental results through quality management in the activity of supreme audit institutions in various states based on industrial and manufacturing engineering under the optimistic scenario

Source: calculated and constructed by the authors.

According to Figure 6, under the optimistic scenario, maximization of environmental results makes it possible to decrease the level of environmental pollution to $0(-99,10 \%)$ and to increase the Climate Index to 89.37 points $(+17.39 \%)$. This requires an increase in the strength of auditing and accounting standards to 96 points $(+33.57 \%)$ and an increase in the degree of renewable energy regulation to 98 points $(+35.21 \%)$. However, this requires an increase in the degree of beneficial effect of the factor of industrial and manufacturing engineering to a level that is unattainable under the current technological mode: The Digital Competitiveness Index should increase to 151.06 points $(+98.17 \%)$.
According to Figure 7, under the realistic scenario, maximization of environmental results makes it possible to decrease the level of environmental pollution to 27.65 points ($42,08 \%)$ and to increase the Climate Index to 80.24 points $(+5.39 \%)$. This requires an increase in the strength of auditing and accounting standards to 83.33 points $(+15.95 \%)$ and an increase in the degree of renewable energy regulation to 80.59 points $(+11.19 \%)$. This requires an increase in the degree of beneficial effect of the factor of industrial and manufacturing engineering to a level that is attainable under the current technological mode: The Digital Competitiveness Index should increase to 100 points $(+31.19 \%)$. 


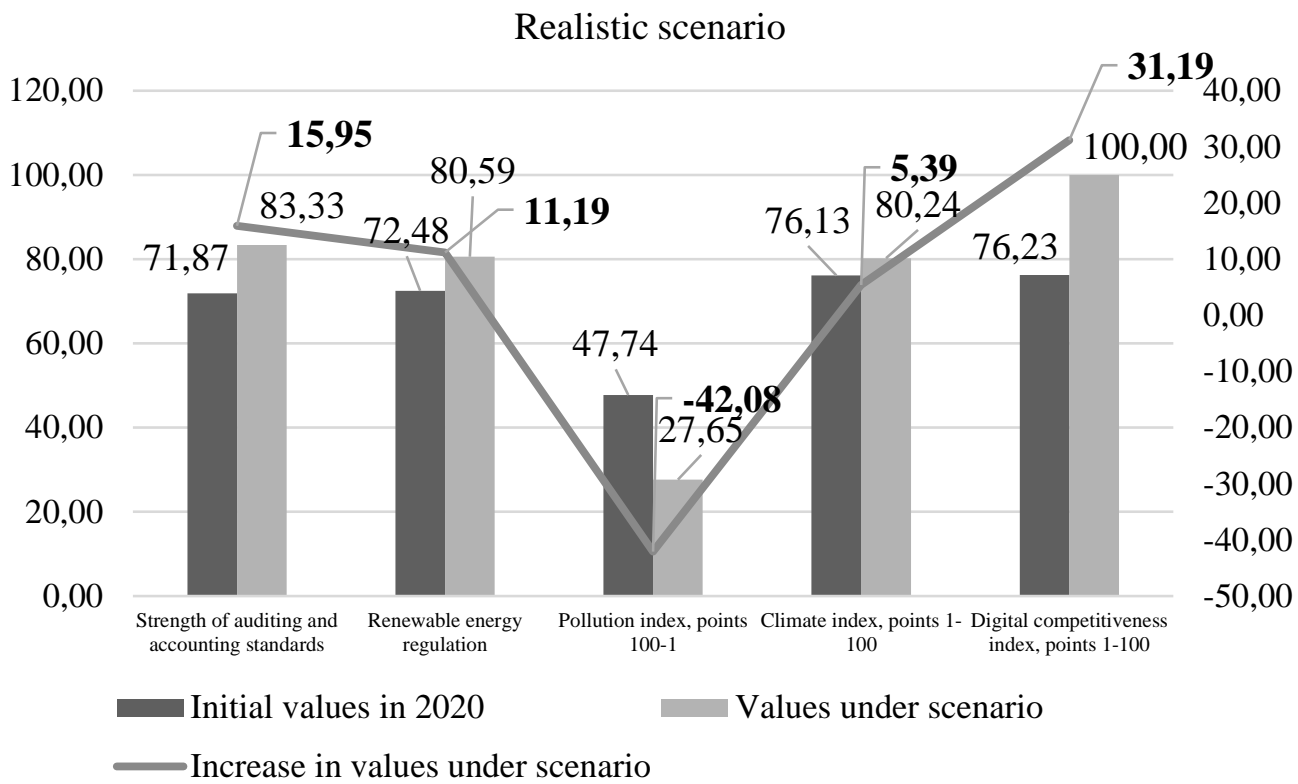

Figure 7. Maximization of environmental results through quality management in the activity of supreme audit institutions in various states based on industrial and manufacturing engineering under the realistic scenario

Source: calculated and constructed by the authors.

\section{Discussion}

The comments of researchers on environmental auditing have been examined in the course of the research. Most international financial institutions and organizations in their publications believe that it is necessary to promote such development that would be sustainable from an economic and environmental point of view, and, to a lesser extent, comments on results of environmental audit, while paying attention to priorities of the activity in environmental management and environmental protection. For example, Karol Mitrík (2020), the President of the Supreme Audit Office of the Republic of Slovakia, the society believes and the parties concerned throughout the world are increasingly assigning public administrations with the tasks to demonstrate and improve the performance of sustainable development. It stands to reason that public opinion also has its impact on the quality of natural resources with account of all national regulations, including for the preservation of the natural environment.

Auditing is the central core of any accountability system and, if held properly, helps public institutions to act in accordance with principles of accountability and good faith, to increase their operating efficiency and the level of people's trust in authorities (Chêne, 2018).

Dulkis (2020), speaking about the control authorities of enterprises, notes that there are no government reports with the analysis of their activity. This opinion confirms the fact that the progress made by an internal audit institution in the field of environmental protection helps preventing damage and minimizing the risks of emergencies in the utilization of the natural environment.

Nelson Shack Yalta (Comptroller General of the Republic of Peru) is of the opinion that 
one should determine the degree of implementation of internal control system in an institution during the audit to guarantee the reliability of revealed factual material.

Chkhutiashvili L., adheres to the same position, believing that environmental audit is an effective form of financial control of environmental and economic activities of enterprises.

Many papers, including the UNESCO report, emphasize that the transition to environmental path of development requires increased attention to the field of training of specialists in environmental audit.

It is not by chance that the International Organization of Supreme Audit Institutions (INTOSAI) constantly gives the highest priority to training of personnel for environmental auditing. For example, in 2010, ECOSAI held an international workshop on environmental auditing in Antalya, Turkey. A similar seminar was held in the Republic of Azerbaijan.

In February 2019, the Supreme Audit Institution of the Republic of the Union of Myanmar and the Supreme Audit Institution of Norway held a joint workshop on environmental audit in Naypyidaw, Myanmar. The workshop was developed with a view to introducing environmental audits in accordance with the International Standards for Supreme Audit Institutions (ISSAI). Experts from Norway presented the definitions of concepts, theories, structures, relevant standards and guidelines for environmental auditing, and discussed the performance audit from an environmental point of view.

In view of expressed points of view, we also believe that environmental auditing requires accredited specialists who not only master auditing methods, but are also familiar with economics of environmental management.

All the more so, as the economic mechanism of environmental management in many countries is an ecologically-oriented set of structures, forms and methods of environmental management.

\section{Conclusions}

Foreign experience of functioning of supreme audit institutions, analyzed by means of a case study, is indicative of a growing trend towards expansion of the scope of application of environmental audit with the use of various types of audit, introduction of new methods of reception of audit evidence and with due account for experience of interaction with the parties concerned. The improvement of quality of professional skills of specialists in environmental auditing, regular training, exchange of experience and cooperation of states in environmental protection serve as a basis for sustainable development of states.

The working hypothesis has been verified as a result of empirical research based on international experience for 2020, and it has been proved that: First, quality management in the activity of supreme audit institutions in various states determines environmental results. Thus, with a 1-point increase in the strength of auditing and accounting standards, there is a 1.33-point decrease in the level of environmental pollution. With a one-point increase in the degree of renewable energy regulation, there is a 0.59 point decrease in the level of environmental pollution. With a one-point increase in the degree of renewable energy regulation, Climate Index increases by 0.54 points.

Industrial and manufacturing engineering factor largely determines quality manifestations in environmental protection in the activity of supreme audit institutions in various states. For example, with a onepoint increase in the Digital Competitiveness Index, there is a 0.4822 -point increase in the strength of auditing and accounting standards and a 0.341-point increase in the degree of renewable energy regulation. This has served as a basis for the development of recommendations to manage the quality of environmental protection in the activity of 
supreme audit institutions in various states based on industrial and manufacturing engineering.

The authors' recommendations are oriented toward a realistic (feasible) scenario and involve ensuring the beneficial effect of industrial and manufacturing engineering by increasing the degree of beneficial effect of industrial and manufacturing engineering factor to 100 points $(+31.19 \%)$. This will cause an increase in the strength of auditing and accounting standards to 83.33 points $(+15.95 \%)$ and an increase in the degree of renewable energy regulation to 80.59 points $(+11.19 \%)$. As a result, this allows decreasing the level of environmental pollution to 27.65 points $(-42.08 \%)$ and increasing the Climate Index to 80.24 points $(+5.39 \%)$.

The contribution of the research to the development of economic science and practice consists in the justification of the need and the development of applied recommendations and reference values of benchmarks in the field of the quality management of environmental protection in the activity of supreme audit institutions in various states based on industrial and manufacturing engineering. These recommendations will be beneficial to developed and developing countries worldwide.

\section{References:}

Audit Chamber of the Russian Federation (2017). Performance statement in the field of environmental protection for 2017-2020. Retrieved from //ach.gov.ru (28.11.2020).

Chêne, M. (2018). The role of supreme audit institutions in fighting corruption / U4 AntiCorruption Resource Center. Retrieved from https://www.u4.no/publications/the-role-ofsupreme-audit-institutions-in-fighting-corruption.pdf. (28.11.2020).

Di Giacomo, N., Guthrie, J., \& Farneti, F. (2017). Environmental management control systems for carbon emissions. PSU Research Review, 1(1), 39-50. https://doi.org/10.1108/PRR-102016-0004

Dulkis, A. (2020). Due Management: An Outlook on the Free-Rider Problem. Retrieved from https://www.intosaijournal.org/ (28.11.2020).

Efimova, N., \& Terekhina S. (2016). Organization of a risk-based system of functioning of economic entities. Moskva. Argamak-Media. 320 p.

Fulton, C. (2020). Collaborating in online teaching: inviting e-guests to facilitate learning in the digital environment. Information and Learning Sciences, 121(7/8), 579-585. https://doi.org/10.1108/ILS-04-2020-0116

Henri, J.-F., Journeault, M., \& Brousseau, C. (2017). Eco-control change and environmental performance: a longitudinal perspective. Journal of Accounting \& Organizational Change, 13(2), 188-215. https://doi.org/10.1108/JAOC-04-2016-0023

IMD (2020). World Digital Competitiveness Report 2020. Retrieved from https://www.imd.org/wcc/world-competitiveness-center-rankings/world-digitalcompetitiveness-rankings-2020/ (28.11.2020).

INTOSAI (2020). 2014 - 2016 Progress Report of the INTOSAI Working Group on Environmental Auditing. Working Group on Environmental Auditing. Retrieved from https://present5.com/2014-2016-progress-report-of-the-intosai/ (28.11.2020).

Klimanov, V. V., Kazakova, S. M., \& Mikhaylova, A. A. (2019). Functions of Supreme Audit Institutions in Russia and Foreign Countries. Financial Journal, 4(1), 60-74. doi: 10.31107/ 2075-1990-2019-4-60-74. 
Kumar, S., Meena, H. M., \& Verma, K. (2017). Water Pollution in India: Its Impact on the Human Health: Causes and Remedies. International Journal of Applied Environmental Sciences, 12(2), 275-279. http://www.ripublication.com.

Ma, C. (2017). Fixed-time compliant motion/force control of robotic manipulators with environmental constraints. Assembly Automation, 37(3), 271-277. https://doi.org/10.1108/AA-11-2016-158

Makarova, A., Tarasova, N., \& Meshalkin, V., (...), Kantyukov, R., Reshetova, E. (2018). Analysis of the management system in the field of environmental protection of Russian chemical companies. International Journal for Quality Research, 12(1), 43-62.

Meng, L., Huang, X., Wei, Q., Ji, D., \& Wang, Q. (2020). Study on the influence of atmospheric environment on the morphology and conductivity of nanoscale copper films sputtered on polyester substrates. International Journal of Clothing Science and Technology, 32(5), 621-629. https://doi.org/10.1108/IJCST-03-2019-0045

Ministry of Finance of the Russian Federation (2019). Review of budget expenditures for the implementation of government programs in the field of environmental management and environmental protection. Moscow 2019. Retrieved from www.minfin.ru//file:///C:/Users/User/AppData/Local/Microsoft/Windows/INetCache/Conten t/Outlook/D5WRCW0J/5.pdf (28.11.2020).

Mitrik, K. (2020). Supreme Audit Institution stresses the equal importance of quality and inspections through personal example. Retrieved from https://www.intosaijournal.org/ (28.11.2020).

Muthukannan, M., Ganesh, A.S.C. (2019). The environmental impact caused by the ceramic industries and assessment methodologies. International Journal for Quality Research, 13(2), 315-334.

Numbeo (2020). Quality of Life Index by Country 2020 Mid-Year. Retrieved from https://www.numbeo.com/quality-of-life/rankings_by_country.jsp (28.11.2020).

Ong, T. S., Magsi, H. B., \& Burgess, T. F. (2019). Organizational culture, environmental management control systems, environmental performance of Pakistani manufacturing industry. International Journal of Productivity and Performance Management, 68(7), 12931322. https://doi.org/10.1108/IJPPM-05-2018-0187

Rahman, M. S., Hossain, M. A., Abdel Fattah, F. A. M., \& Akter, S. (2020). Optimizing competitive performance of service firms in data-rich environment. Journal of Service Theory and Practice, 30(6), 681-706. https://doi.org/10.1108/JSTP-04-2020-0077

Ralston, P. M., Keller, S. B., \& Grawe, S. J. (2020). Collaborative process competence as an enabler of supply chain collaboration in competitive environments and the impact on customer account management. The International Journal of Logistics Management, 31(4), 905-929. https://doi.org/10.1108/IJLM-11-2019-0310

Rötzel, P. G., Stehle, A., Pedell, B., \& Hummel, K. (2019). Integrating environmental management control systems to translate environmental strategy into managerial performance. Journal of Accounting \& Organizational Change, 15(4), 626-653. https://doi.org/10.1108/JAOC-08-2018-0082

Walimuni, P. C., Samaraweera, A., \& De Silva, L. (2017). Payment mechanisms for contractors for better environmental hazard controlling in road construction projects. Built Environment Project and Asset Management, 7(4), 426-440. https://doi.org/10.1108/BEPAM-11-2016-0069 
World Economic Forum (2020). The Global Competitiveness Report 2019. Retrieved from http://reports.weforum.org/global-competitiveness-report-2019/competitivenessrankings/\#series=ENVTREATY (28.11.2020).

\begin{tabular}{lll}
\hline \hline Nina P. Efimova & Aleksandr A. Vasilev & Anatoly B. Yaroshchuk \\
Lomonosov Moscow State & Lomonosov Moscow State & State University of \\
University, Moscow, Russia & University, Moscow, Russia & Management, Moscow, \\
efimova_np@list.ru & $\underline{\text { ofz-rf@yandex.ru }}$ & Russia \\
& & $\underline{\text { Yab.58@mail.ru }}$ \\
\hline \hline
\end{tabular}




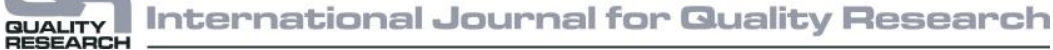

